\title{
Feather growth, bodyweight and body temperature in broiler lines with different feathering rates
}

\author{
M. Noubandiguim ${ }^{1,2 \#}$, K. Erensoy ${ }^{3} \&$ M. Sarica ${ }^{3}$ \\ ${ }^{1}$ Department of Biology, Faculty of Art and Sciences, Ondokuz Mayis University, Samsun, 55139, Turkey \\ ${ }^{2}$ Département des Sciences Techniques d'Elevage, Institut National Supérieur des Sciences et Techniques d'Abéché \\ (INSTA), Abéché, Bp130, Chad \\ ${ }^{3}$ Department of Animal Science, Agricultural Faculty, Ondokuz Mayis University, Samsun, 55139, Turkey
}

(Submitted 5 June 2020; Accepted; 19 November 2020; Published 15 January 2021)

\author{
Copyright resides with the authors in terms of the Creative Commons Attribution 4.0 South African Licence. \\ See: http://creativecommons.org/licenses/by/4.0/za \\ Condition of use: The user may copy, distribute, transmit and adapt the work, but must recognise the authors and the South African \\ Journal of Animal Science.
}

\begin{abstract}
Two early feathering sire lines (B1 and B2), two late feathering dam lines (A1 and A3), and an early feathering dam line were evaluated to determine differences in growth, in lengths of primary feathers, in under-wing and rectal temperatures, and in feed intake until the birds were 20 weeks old. The chicks were hatched from eggs collected from 35-week-old hens of pure line broiler flocks. Data were collected at hatch, and at 1, 2, 4, 6, 8, 12, and 20 weeks old Thirty males and 30 females were evaluated for each line. The early feathering genotypes (A2, B1 and B2) had longer primary feathers until they were six weeks old. They also had higher under-wing and rectal temperatures and higher live weight compared with the late-feathering lines (A1 and A3) at one and two weeks old. The males were heavier than females at all ages. However, under-wing and rectal temperatures were similar in males and females at all ages. A positive correlation was observed between the length of primary feathers and live weight in A2, B1, and B2 at six weeks, whereas a negative correlation was observed between the rectal temperature and the length of primary feathers in $A 1$ and $\mathrm{A} 3$ at 4 and 20 weeks old.
\end{abstract}

Keywords: feather length, rectal temperature, under-wing temperature \#Corresponding Author: noubandiguim@gmail.com

\section{Introduction}

In birds, feathers are important for physical protection, insulation, thermal control, sexual display, and flight (Cangar et al., 2008; Khosravinia, 2009). They provide considerable thermal insulation, which can contribute to maintaining body temperature within the normal range and thus have an influence on traits of economic importance (Fotsa et al., 2001; Khosravinia, 2009). In high temperature situations, poor feathering may minimize the elevation in body temperature and improve thermoregulation (Yalcin et al., 1997; Sharifi, 2004). Thus, feathers provide desirable insulation in cold weather and hinder heat loss under hot conditions (Cangar et al., 2008). However, feathers are not evenly distributed on the body (Nickel et al., 1992). The abundance of feathers may be affected by factors such as genotype, age, sex, nutrition, and production system. Although the genetic variability of feather distribution in a normal feathering chicken is unknown, it can be altered by several major genes. A sex-linked gene (K), first reported by Serebrovsky (1922), affects the rate of feathering, and is responsible for the early and late feathering trait in chicken. Later Warren (1925) confirmed this discovery, and demonstrated that late feathering was dominant to early feathering. Late feathering chicks have significantly shorter tail feathers than the early feathering genotypes at ten days old, whereas early feathering chicks have longer primary feathers than their later feathering counterparts (Darrow \& Warren, 1944; Hays, 1952).

The industry uses the relative length of the primary and secondary feathers to sex day-old chicks, thus providing an accurate and cost-effective method of determining sex immediately after hatch (Xie et al., 2013; Derks et al., 2018). In addition, interest in the broiler industry has led to scientific characterization of the $\mathrm{K}$ gene, resulting in the discovery of its pleiotropic effects. Many studies documented a preference for early feathering in broilers because it was associated with an 
increased rate of growth because of more effective protection against chilling, and reduced feather picking and cannibalism (Fotsa et al., 2001; Mahmoud et al., 2018). If the birds have better insulation against heat loss (Yalcin et al., 1997), more energy is available for growth, because less is used to maintain body temperature (Dunnington \& Siegel, 1985; Katanbaf et al., 1989). However, other studies reported no difference in the growth rate of early and late feathering birds (Hays, 1951; Godfrey \& Farnsworth, 1952).

Limited studies relate feather growth and body temperature to production traits. Chen et al. (2013) showed that the body temperature could be used to evaluate comfort and thermal equilibrium in animals. Because of the insulation provided by feathers on most of the body, the body surface temperature of broilers varies according to where it is measured and the age of the birds (Richards, 1971). Under the wing is considered one of the warmest places on birds (Moghbeli et al., 2018). Therefore, the purpose of this study was to investigate the effects of genotypes, which differ in the rate of feathering, and of sex on the length of primary feathers, under-wing and rectal temperature, and bodyweight during the growth period.

\section{Material and methods}

The experiment was conducted at the Agricultural Faculty Experimental Farm of Ondokuz Mayis University from May to July 2018. All procedures were approved by Ondokuz Mayis University Ethical Committee for Experimental Animals under protocol number 2017_31.

The broiler strains used in this study were five pure lines that differed in rate of feathering. Three were dam lines (A1: late feathering, A2: early feathering and A3: late feathering) and two were early feathering sire lines (B1 and B2). These lines are used for breeding at the Transitional Zone Agricultural Research Institute in Eskişehir, Turkey. They were founded from 50 and 35 families in the dam and sire lines, respectively. A general characterization of these lines is given in Table 1.

Table 1 Phenotypic description of broiler sire and dam lines used to investigate effects feathering on body temperature and performance of broiler chickens

\begin{tabular}{|c|c|c|c|c|c|c|c|c|}
\hline \multirow{2}{*}{\multicolumn{2}{|c|}{ Lines }} & \multirow{2}{*}{ Feathering } & \multirow{2}{*}{$\begin{array}{l}\text { ASM, } \\
\text { days }\end{array}$} & \multicolumn{2}{|c|}{$\begin{array}{c}\text { Bodyweight at sexual } \\
\text { maturity, g }\end{array}$} & \multicolumn{2}{|c|}{$\begin{array}{c}\text { Bodyweight at } 26 \text { weeks, } \\
\mathrm{g}\end{array}$} & \multirow{2}{*}{$\begin{array}{l}\text { Egg production to } \\
52 \text { weeks }^{1}\end{array}$} \\
\hline & & & & Males & Females & Males & Females & \\
\hline \multirow{3}{*}{ Dam } & $\mathrm{A} 1$ & Late & 171 & 3430 & 3035 & 3512 & 3146 & 119 \\
\hline & A2 & Early & 176 & 3450 & 3272 & 3583 & 3355 & 115 \\
\hline & A3 & Late & 170 & 3280 & 2907 & 3312 & 3087 & 120 \\
\hline \multirow{2}{*}{ Sire } & B1 & Early & 175 & 3630 & 3377 & 3767 & 3554 & 78 \\
\hline & B2 & Early & 171 & 3680 & 3229 & 3766 & 3407 & 90 \\
\hline
\end{tabular}

ASM: age at sexual maturity

${ }^{1}$ Sarica et al. (2016)

Four hundred and fifty chicks (mixed sex) were weighed and distributed into fifteen $1.8 \times 2.2 \mathrm{~m}$ floor pens in a curtain-sided cross-ventilated house. During the first six weeks of the experiment, the 15 pen experimental units were divided into five treatments (according to genotype) with three replicate pens of 30 chicks for each genotype. The chicks were wing-banded one day after hatching, and sexed at six weeks old. All chicks received continuous lighting (23 hours light: 1 hour darkness) for the first three days. Lighting was decreased incrementally to eight hours at two weeks and remained constant until the chicks were 20 weeks old. Brooding temperature was $33^{\circ} \mathrm{C}$ for the first three days and decreased gradually to $21^{\circ} \mathrm{C}$ at 28 days. Then the temperature and humidity ranged between $21^{\circ} \mathrm{C}$ and $25^{\circ} \mathrm{C}$ and $50 \%$ and $60 \%$, respectively. The chicks were fed for ad libitum intake until two weeks old, with restricted feeding beginning at three weeks and continuing until the birds were 20 weeks old. The feed offered was adjusted weekly to achieve the desired bodyweight gain. The diet varied with age (Table 2). Water was provided ad libitum. Chicks were vaccinated against Newcastle, Gumboro, and Infectious Bronchitis, and no health problems were observed during the experiment. 
Table 2 Nutrient compositions of the diets fed to broiler chicks in investigating effects of early and late feathering

\begin{tabular}{lccc}
\hline Nutritional composition & $\begin{array}{c}\text { Starter } \\
(1-3 \text { weeks })\end{array}$ & $\begin{array}{c}\text { Grower } \\
(4-10 \text { weeks })\end{array}$ & $\begin{array}{c}\text { Developer } \\
(11-20 \text { weeks })\end{array}$ \\
\hline Crude protein, \% & 20.00 & 18.00 & 14.00 \\
Metabolizable energy, kcal/kg & 2750 & 2750 & 2630 \\
Crude cellulose, \% & 7.00 & 7.00 & 7.00 \\
Calcium, \% & 1.00 & 1.00 & 1.00 \\
Available phosphorus, \% & 0.45 & 0.45 & 0.35 \\
Choline, mg/kg & 1300 & 1300 & 1000 \\
Linoleic acid, \% & 1.00 & 1.00 & 0.85 \\
\hline
\end{tabular}

The length of primary feathers and under-wing and rectal body temperatures were recorded at hatching, and when the birds were $1,2,4,6,8,12$, and 20 weeks old. The length of the primary feathers was measured by inserting a tape rule $(\mathrm{cm})$ between two feathers until it touched the skin. The maximum length of the fourth primary was used in this study. The under-wing temperature was measured with an infrared thermometer with a temperature range of $20^{\circ} \mathrm{C}$ to $120^{\circ} \mathrm{C}$, and absolute accuracy of $\pm 2{ }^{\circ} \mathrm{C}$. The rectal temperature was measured with an electronic digital thermometer (AZLZM, Germany) with a temperature range of $32{ }^{\circ} \mathrm{C}$ to $43{ }^{\circ} \mathrm{C}$ and resolution of $0.1{ }^{\circ} \mathrm{C}$. To acquire the rectal temperature, the thermometer was inserted approximately $3 \mathrm{~cm}$ into the cloaca and was read after the temperature stabilized at typically 30 to 45 seconds. All temperatures were obtained during a two-hour interval after 12 hours of feed withdrawal.

Data from the study were analysed as a $5 \times 2$ factorial using SPSS 25.0 (IBM Corp., Armonk, New York, USA) to assess the main effects and two-way interaction. The data were evaluated as fixed effects using the statistical model:

$$
Y_{i j k}=\mu+\text { Genotype }_{i}+\text { Sex }_{j}+\left(\text { Genotype } \times \operatorname{Sex}_{i j}+e_{i j k}\right.
$$

where: $Y_{\mathrm{ijk}}$ was the dependent variable,

$\mu$ was the overall mean,

Genotype was $_{\text { }}$ genotype effects $(i=1 \sim 5)$,

Sex $x_{j}$ was sex effects $(j=$ male and female)

(genotype and sex $)_{\mathrm{ij}}$ was the interaction effect between ith genotype and jth sex, and

$\mathrm{e}_{\mathrm{ijk}}$ was observational error for an observation of the dependent variable.

Tukey's test was used to make pairwise comparisons between treatment means $(P<0.05)$. Pearson correlation test was used to determine the relationships between lengths of primary feathers, rectal and under-wing temperatures, and bodyweights.

\section{Results and Discussion}

Daily feed intake of pure lines is given in Table 3. Males and females of all genotypes consumed an equal amount of feed during the first six weeks of the growing period. At 6 weeks old chicks were sexed, reared separately in litter-floor pens and fed according to breeder recommendations.

Live weight differed significantly among the broiler pure lines through four weeks old and between sexes throughout the study (Table 4). The interaction of genotype and sex was not significant at any age. Chick weights at hatching were significantly greater for the A3 genotype, with little difference among the others. It was observed that the $\mathrm{A} 1$ and $\mathrm{A} 3$ genotypes were slightly heavier compared with their early feathering contemporaries (A2, B1, and B2). At one and two weeks old the B2 genotype was significantly heavier than A1 with the B1, A2, and A3 genotypes being intermediate. At four weeks, the only difference in live weight was the A1 genotype being lighter than the other genotypes $(P<0.01)$. After the birds were six weeks old, no significant differences in live weight were detected among the genotypes. However, the data showed a numerical advantage in live weight for the early feathering genotypes at six weeks old. Males were significantly heavier than females at all ages. 
Table 3 Feed intake (grams) of broiler pure lines at various ages

\begin{tabular}{|c|c|c|c|c|c|c|c|c|}
\hline \multirow{2}{*}{ Genotypes } & \multirow{2}{*}{ Sex } & \multicolumn{7}{|c|}{ Age, weeks } \\
\hline & & 1 & 2 & 4 & 6 & 8 & 12 & 20 \\
\hline \multirow{2}{*}{$\mathrm{A} 1$} & M & \multirow{2}{*}{20.0} & \multirow{2}{*}{30.0} & \multirow{2}{*}{32.0} & \multirow{2}{*}{46.0} & 65.0 & 74.0 & 112.0 \\
\hline & $\mathrm{F}$ & & & & & 47.0 & 52.0 & 96.0 \\
\hline \multirow{2}{*}{ A2 } & M & \multirow{2}{*}{20.0} & \multirow{2}{*}{30.0} & \multirow{2}{*}{32.0} & \multirow{2}{*}{46.0} & 65.0 & 74.0 & 108.0 \\
\hline & $\mathrm{F}$ & & & & & 56.0 & 52.0 & 96.0 \\
\hline \multirow{2}{*}{ A3 } & M & \multirow{2}{*}{20.0} & \multirow{2}{*}{30.0} & \multirow{2}{*}{32.0} & \multirow{2}{*}{46.0} & 65.0 & 74.0 & 112.0 \\
\hline & $\mathrm{F}$ & & & & & 56.0 & 52.0 & 96.0 \\
\hline \multirow{2}{*}{ B1 } & M & \multirow{2}{*}{20.0} & \multirow{2}{*}{30.0} & \multirow{2}{*}{32.0} & \multirow{2}{*}{46.0} & 65.0 & 74.0 & 102.0 \\
\hline & $\mathrm{F}$ & & & & & 56.0 & 52.0 & 96.0 \\
\hline \multirow{2}{*}{ B2 } & M & \multirow{2}{*}{20.0} & \multirow{2}{*}{30.0} & \multirow{2}{*}{32.0} & \multirow{2}{*}{46.0} & 65.0 & 74.0 & 102.0 \\
\hline & $\mathrm{F}$ & & & & & 56.0 & 52.0 & 96.0 \\
\hline
\end{tabular}

M: male; F: female

Table 4 Live weight mean (grams) for male and female birds from the pure lines of broilers at various ages

\begin{tabular}{crrrrrrrr}
\hline \multirow{2}{*}{ Genotypes } & \multicolumn{7}{c}{ Age, weeks } \\
\cline { 2 - 8 } & \multicolumn{1}{c}{1} & \multicolumn{1}{c}{ 1 } & \multicolumn{1}{c}{4} & \multicolumn{1}{c}{6} & \multicolumn{1}{c}{12} & \multicolumn{1}{c}{20} \\
\hline A1 & $43.1^{\mathrm{b}}$ & $144.1^{\mathrm{c}}$ & $323.2^{\mathrm{c}}$ & $480.9^{\mathrm{b}}$ & 806.6 & 1124.1 & 1560.3 & 2218.2 \\
A2 & $42.8^{\mathrm{b}}$ & $153.4^{\mathrm{b}}$ & $352.3^{\mathrm{b}}$ & $564.1^{\mathrm{a}}$ & 843.9 & 1161.4 & 1680.0 & 2310.9 \\
A3 & $45.8^{\mathrm{a}}$ & $149.9^{\mathrm{bc}}$ & $338.5^{\mathrm{bc}}$ & $555.5^{\mathrm{a}}$ & 813.1 & 1114.1 & 1580.2 & 2277.6 \\
B1 & $42.1^{\mathrm{b}}$ & $159.2^{\mathrm{b}}$ & $347.2^{\mathrm{b}}$ & $557.7^{\mathrm{a}}$ & 853.6 & 1176.2 & 1681.9 & 2359.8 \\
B2 & $43.6^{\mathrm{b}}$ & $166.7^{\mathrm{a}}$ & $374.4^{\mathrm{a}}$ & $562.9^{\mathrm{a}}$ & 856.6 & 1163.3 & 1762.2 & 2385.5 \\
Standard error & 0.22 & 0.89 & 2.21 & 3.79 & 6.77 & 10.7 & 22.5 & 36.8 \\
Male & 43.5 & $157.2^{\mathrm{a}}$ & $353.3^{\mathrm{a}}$ & $554.9^{\mathrm{a}}$ & $853.6^{\mathrm{a}}$ & $1206.7^{\mathrm{a}}$ & $1833.1^{\mathrm{a}}$ & $2904.5^{\mathrm{a}}$ \\
Female & & $152.0^{\mathrm{b}}$ & $340.9^{\mathrm{b}}$ & $527.3^{\mathrm{b}}$ & $803.9^{\mathrm{b}}$ & $1060.0^{\mathrm{b}}$ & $1387.7^{\mathrm{b}}$ & $2066.1^{\mathrm{b}}$ \\
Standard error & 0.10 & 0.56 & 1.39 & 2.40 & 4.28 & 6.76 & 14.3 & 23.3 \\
\hline
\end{tabular}

M: male, F: female

${ }_{\mathrm{a}, \mathrm{b}, \mathrm{c}}$ Within a column, means with a common superscript did not differ with probability $P=0.05$

The length of the primary feathers differed significantly among the broiler pure lines through eight weeks old and between sexes, except when the birds were four and twelve weeks old (Table 5). The interaction of genotype and sex was not significant at any age. From hatch to two weeks old primary feathers of $\mathrm{B} 1, \mathrm{~B} 2$, and $\mathrm{A} 2$ genotypes was significantly longer $(P<0.01)$ than those of $\mathrm{A} 1$ and $\mathrm{A} 3$, and females had longer feathers than males $(P<0.05)$. At four weeks, B1 and B2 genotypes had long primary feathers, followed by $A 2, A 3$, and $A 1$, but there was no significant difference in the length of primary feathers between females and males $(P>0.05)$. At six and eight weeks old the primary feathers were longer $(P<0.01)$ in $\mathrm{B} 1$, $B 2$, and A2 genotypes than in A1 and A3. The greater length of primary feathers that had been observed in females shifted to the males at six weeks $(P<0.05)$. However, at 12 weeks and 20 weeks, there were no significant differences in the length of primary feathers among the five genotypes. 
Table 5 Length $(\mathrm{cm})$ of primary feathers for male and female birds from the pure lines of broilers at various ages

\begin{tabular}{ccccccccc}
\hline \multirow{2}{*}{ Genotype } & \multicolumn{7}{c}{ Age, weeks } \\
\cline { 2 - 9 } & 0 & 1 & 2 & 4 & 6 & 8 & 12 & 20 \\
\hline A1 & $1.01^{\mathrm{b}}$ & $3.40^{\mathrm{b}}$ & $5.31^{\mathrm{b}}$ & $7.80^{\mathrm{c}}$ & $9.98^{\mathrm{b}}$ & $11.51^{\mathrm{b}}$ & 14.51 & 15.63 \\
A2 & $1.57^{\mathrm{a}}$ & $5.32^{\mathrm{a}}$ & $6.25^{\mathrm{a}}$ & $8.57^{\mathrm{b}}$ & $10.61^{\mathrm{a}}$ & $11.69^{\mathrm{ab}}$ & 14.29 & 16.54 \\
A3 & $0.98^{\mathrm{b}}$ & $3.51^{\mathrm{b}}$ & $5.12^{\mathrm{b}}$ & $7.81^{\mathrm{c}}$ & $10.00^{\mathrm{b}}$ & $11.52^{\mathrm{b}}$ & 14.52 & 16.08 \\
B1 & $1.53^{\mathrm{a}}$ & $5.25^{\mathrm{a}}$ & $6.33^{\mathrm{a}}$ & $9.53^{\mathrm{a}}$ & $10.66^{\mathrm{a}}$ & $11.90^{\mathrm{a}}$ & 14.24 & 16.01 \\
B2 & $1.56^{\mathrm{a}}$ & $5.26^{\mathrm{a}}$ & $6.42^{\mathrm{a}}$ & $9.56^{\mathrm{a}}$ & $10.67^{\mathrm{a}}$ & $11.95^{\mathrm{a}}$ & 14.22 & 16.59 \\
\hline Standard error & 0.16 & 0.06 & 0.05 & 0.06 & 0.04 & 0.04 & 0.06 & 1.14 \\
$\quad$ Male & 1.29 & $4.44^{\mathrm{b}}$ & $5.75^{\mathrm{b}}$ & 8.60 & $10.55^{\mathrm{a}}$ & $11.83^{\mathrm{a}}$ & 14.25 & $16.67^{\mathrm{a}}$ \\
Female & & $4.70^{\mathrm{a}}$ & $6.10^{\mathrm{a}}$ & 8.55 & $10.22^{\mathrm{b}}$ & $11.56^{\mathrm{b}}$ & 14.58 & $15.48^{\mathrm{b}}$ \\
Standard error & 0.07 & 0.04 & 0.03 & 0.04 & 0.03 & 0.02 & 0.04 & 0.72 \\
\hline
\end{tabular}

M: male, F: female

${ }_{a, b, c}$ Within a column, means with a common superscript did not differ with probability $P=0.05$

Under-wing temperature differed significantly among the broiler pure lines through four weeks old and at 12 weeks old (Table 6). The difference between males and females in under-wing temperature was significant only at two weeks old. The interaction of genotype and sex was not significant at any age. At hatch, there were no significant differences among the genotypes in under-wing temperature $(P>0.05)$. At one week, the under-wing temperatures were higher $(P<0.05)$ in $\mathrm{B} 1$ and $\mathrm{A} 2$ than in $\mathrm{A} 3$, with $\mathrm{B} 2$ and $\mathrm{A} 1$ being intermediate and not different from either of the extremes. At two weeks, under-wing temperatures were higher in the early feathering genotypes than in their late feathering counterparts $(P<0.01)$. At four weeks, the early feathering $A 1$ genotype had a lower under-wing temperature than the other genotypes $(P$ $<0.01$ ) and at 12 weeks the dam lines had lower under-wing temperatures than the sire lines.

Table 6 Under-wing temperatures $\left({ }^{\circ} \mathrm{C}\right)$ for male and female birds from the pure lines of broilers at various ages

\begin{tabular}{|c|c|c|c|c|c|c|c|c|}
\hline \multirow{2}{*}{ Genotypes } & \multicolumn{8}{|c|}{ Age (weeks) } \\
\hline & 0 & 1 & 2 & 4 & 6 & 8 & 12 & 20 \\
\hline A1 & 36.58 & $38.47^{\mathrm{ab}}$ & $39.01^{b}$ & $40.21^{b}$ & 40.16 & 40.09 & $40.06^{b}$ & 40.04 \\
\hline A2 & 36.71 & $38.60^{\mathrm{a}}$ & $39.81^{\mathrm{a}}$ & $40.50^{\mathrm{a}}$ & 40.17 & 40.08 & $40.07^{b}$ & 40.04 \\
\hline A3 & 36.65 & $38.32^{b}$ & $39.10^{b}$ & $40.53^{\mathrm{a}}$ & 40.16 & 40.08 & $40.05^{\mathrm{b}}$ & 40.03 \\
\hline B1 & 36.66 & $38.53^{\mathrm{a}}$ & $39.80^{\mathrm{a}}$ & $40.42^{\mathrm{a}}$ & 40.17 & 40.08 & $40.60^{a}$ & 40.03 \\
\hline B2 & 36.70 & $38.49^{\mathrm{ab}}$ & $39.83^{a}$ & $40.65^{\mathrm{a}}$ & 40.18 & 40.08 & $40.70^{a}$ & 40.03 \\
\hline Standard error & 0.02 & 0.01 & 0.04 & 0.02 & 0.02 & 0.03 & 0.03 & 0.01 \\
\hline Male & \multirow{2}{*}{36.66} & 38.50 & $39.70^{\mathrm{a}}$ & 40.50 & 40.17 & 40.09 & 40.32 & 40.03 \\
\hline Female & & 38.49 & $39.29^{b}$ & 40.50 & 40.16 & 40.08 & 40.28 & 40.03 \\
\hline Standard error & 0.01 & 0.01 & 0.02 & 0.01 & 0.01 & 0.02 & 0.02 & 0.01 \\
\hline
\end{tabular}

M: male, F: female

a,b,c Within a column, means with a common superscript did not differ with probability $P=0.05$

Rectal temperature differed significantly among the broiler pure lines through two weeks old and again at 12 and 20 weeks (Table 7). Rectal temperature was not significantly affected by sex or the interaction of genotype and sex at any age. At hatching, the rectal temperature of A1 was less than the other genotypes. 
At one week old, rectal temperatures were significantly higher in the early feathering $B 1$, B2, and A2 genotypes than in $\mathrm{A} 1$ and $\mathrm{A} 3(P<0.01)$. At two weeks, rectal temperature in the A2 genotype was elevated compared with the other genotypes $(P<0.01)$. From four weeks to eight, there were no significant differences in all genotypes $(P>0.05)$. At 12 weeks, the rectal temperatures were significantly higher in the sire lines than in the dam lines. At 20 weeks old, rectal temperatures were lower in the B1 genotype compared with other lines $(P<0.01)$.

Table 7 Rectal temperatures $\left({ }^{\circ} \mathrm{C}\right)$ for male and female birds from the pure lines of broilers at various ages

\begin{tabular}{|c|c|c|c|c|c|c|c|c|}
\hline \multirow{2}{*}{ Genotypes } & \multicolumn{8}{|c|}{ Age, weeks } \\
\hline & 0 & 1 & 2 & 4 & 6 & 8 & 12 & 20 \\
\hline A1 & $37.13^{\mathrm{b}}$ & $39.72^{b}$ & $40.61^{b}$ & 41.59 & 41.70 & 41.54 & $41.41^{b}$ & $41.62^{\mathrm{a}}$ \\
\hline A2 & $37.59^{\mathrm{a}}$ & $40.13^{\mathrm{a}}$ & $41.10^{\mathrm{a}}$ & 41.61 & 41.75 & 41.67 & $41.48^{b}$ & $41.77^{\mathrm{a}}$ \\
\hline A3 & $37.71^{\mathrm{a}}$ & $39.80^{\mathrm{b}}$ & $40.67^{b}$ & 41.60 & 41.70 & 41.55 & $41.40^{\mathrm{b}}$ & $41.74^{\mathrm{a}}$ \\
\hline B1 & $37.78^{\mathrm{a}}$ & $40.0^{\mathrm{a}}$ & $40.67^{b}$ & 41.66 & 41.74 & 41.70 & $41.74^{\mathrm{a}}$ & $41.44^{\mathrm{b}}$ \\
\hline B2 & $37.77^{\mathrm{a}}$ & $40.0^{\mathrm{a}}$ & $40.77^{\mathrm{b}}$ & 41.66 & 41.75 & 41.72 & $41.70^{\mathrm{a}}$ & $41.64^{\mathrm{a}}$ \\
\hline Standard error & 0.01 & 0.02 & 0.02 & 0.02 & 0.01 & 0.01 & 0.02 & 0.02 \\
\hline Male & \multirow{2}{*}{37.59} & 39.89 & 40.77 & 41.63 & 41.75 & 41.66 & 41.58 & 41.63 \\
\hline Female & & 39.85 & 40.76 & 41.62 & 41.72 & 41.60 & 41.50 & 41.64 \\
\hline Standard error & 0.01 & 0.01 & 0.01 & 0.01 & 0.01 & 0.01 & 0.01 & 0.01 \\
\hline
\end{tabular}

M: male, F: female

a,b,c Within a column, means with a common superscript did not differ with probability $P=0.05$

There were no significant correlations for the length of primary feathers with under-wing temperature at any age, except in the A2 genotype with a low positive relationship at four weeks old (Table 8). Rectal temperature was negatively correlated $(P<0.05)$ with the length of primary feathers in $\mathrm{B} 2$ at one week old, and in $\mathrm{A} 1$ and $\mathrm{A} 3$ at four weeks. At 20 weeks old, rectal temperature was again negatively correlated $(P$ $<0.01$ ) with the length of primary feathers in $\mathrm{A} 1$ and $\mathrm{A} 3$. Otherwise, under-wing and rectal temperatures were not significantly correlated with the length of primary feathers.

Table 8 Estimates of correlation for length of primary feathers with under-wing and rectal temperatures of broiler pure lines at various ages

\begin{tabular}{cccccccccc}
\hline \multirow{3}{*}{ Temperature } & Genotypes & \multicolumn{7}{c}{ Age (weeks) } \\
\cline { 3 - 10 } & & 0 & 1 & 2 & 4 & 6 & 8 & 12 & 20 \\
\hline \multirow{5}{*}{ Under-wing } & A1 & -0.131 & -0.068 & 0.001 & -0.184 & -0.079 & -0.048 & 0.123 & -0.205 \\
& A2 & -0.080 & -0.099 & -0.116 & $0.379^{*}$ & 0.337 & -0.102 & -0.036 & 0.347 \\
& A3 & 0.088 & 0.188 & 0.338 & -0.017 & 0.201 & 0.012 & -0.027 & 0.242 \\
& B1 & -0.155 & 0.211 & -0.017 & -0.256 & 0.007 & -0.147 & -0.101 & 0.304 \\
& B2 & -0.111 & -0.293 & -0.148 & 0.056 & 0.203 & -0.047 & -0.049 & -0.278 \\
\hline \multirow{5}{*}{ Rectal } & A1 & -0.348 & -0.058 & 0.108 & $-0.441^{*}$ & 0.238 & -0.241 & 0.210 & $-0.389^{* \star}$ \\
& A2 & 0.353 & 0.135 & -0.081 & -0.103 & 0.219 & 0.292 & 0.104 & 0.149 \\
& A3 & 0.240 & 0.008 & -0.097 & $-0.452^{*}$ & -0.258 & 0.031 & -0.100 & $-0.365^{* *}$ \\
& B1 & 0.183 & -0.213 & -0.077 & -0.119 & 0.337 & -0.132 & 0.284 & -0.242 \\
& B2 & 0.266 & $-0.362^{*}$ & -0.173 & 0.054 & 0.219 & 0.056 & -0.382 & -0.295 \\
\hline
\end{tabular}


No significant correlations were recorded between the length of primary feathers and live weight for any of the genotypes at any age (Table 9), except that at six weeks old positive estimates of correlation were observed in the early feathering genotypes (A2, B1 and B2).

Table 9 Estimates of correlation for length of primary feathers with live weight of broiler pure lines at various ages

\begin{tabular}{|c|c|c|c|c|c|c|c|c|c|}
\hline \multirow{2}{*}{ Trait } & \multirow{2}{*}{ Genotypes } & \multicolumn{8}{|c|}{ Age (weeks) } \\
\hline & & 0 & 1 & 2 & 4 & 6 & 8 & 12 & 20 \\
\hline \multirow{5}{*}{ Live weight } & $\mathrm{A} 1$ & 0.134 & -0.296 & -0.126 & -0.008 & -0.065 & -0.090 & 0.181 & 0.322 \\
\hline & A2 & -0.193 & 0.122 & 0.101 & -0.155 & $0.395^{\star}$ & 0.009 & 0.084 & 0.442 \\
\hline & A3 & 0.315 & -0.058 & -0.071 & -0.239 & -0.070 & 0.074 & -0.307 & 0.205 \\
\hline & B1 & 0.143 & 0.157 & 0.328 & 0.159 & $0.389^{*}$ & 0.241 & 0.081 & -0.087 \\
\hline & B2 & 0.097 & 0.009 & 0.196 & 0.167 & $0.398^{*}$ & 0.244 & 0.359 & -0.139 \\
\hline
\end{tabular}

${ }^{*} P=0.05$

From one week old onwards, the rectal and under-wing temperatures were highly correlated (Table 10). At hatching this relationship was weaker.

Table 10 Pearson correlation coefficients between rectal and under-wing temperatures of broiler pure lines at various ages

\begin{tabular}{|c|c|c|c|c|c|c|c|c|}
\hline \multirow{2}{*}{ Genotypes } & \multicolumn{8}{|c|}{ Age (weeks) } \\
\hline & 0 & 1 & 2 & 4 & 6 & 8 & 12 & 20 \\
\hline $\mathrm{A} 1$ & 0.346 & $0.706^{* *}$ & $0.766^{\star *}$ & $0.808^{* *}$ & $0.765^{\star \star}$ & $0.778^{\star *}$ & $0.771^{\star *}$ & $0.762^{* *}$ \\
\hline A2 & 0.292 & $0.638^{* *}$ & $0.728^{\star *}$ & $0.755^{\star \star}$ & $0.795^{\star *}$ & $0.799^{\star *}$ & $0.814^{\star \star}$ & $0.752^{\star \star}$ \\
\hline A3 & 0.322 & $0.762^{* *}$ & $0.763^{* *}$ & $0.779^{\star *}$ & $0.810^{* *}$ & $0.804^{*}$ & $0.805^{\star *}$ & $0.765^{\star \star}$ \\
\hline B1 & 0.313 & $0.794^{* *}$ & $0.808^{\star *}$ & $0.769^{* *}$ & $0.806^{* *}$ & $0.741^{* *}$ & $0.789^{\star *}$ & $0.804^{\star \star *}$ \\
\hline B2 & 0.222 & $0.662^{* *}$ & $0.776^{\star *}$ & $0.807^{* *}$ & $0.798^{* *}$ & $0.863^{* *}$ & $0.769^{\star *}$ & $0.749^{\star *}$ \\
\hline
\end{tabular}

${ }^{* *} P<0.01$

Pure line flocks are used to develop parents and to provide material for broiler production. Restricted feed programmes are used to control early growth in pure lines relative to the breeding objectives (Arrazola et al., 2020). Similarly, in this study, birds were subjected to restricted feeding programmes so that the birds would grow according to the growth curve that was desired by the breeding company. Thus, the feed offered could be changed if a genotype had higher or lower live weight at a specific age than the target bodyweight. These managerial interventions explain some differences in feed intake among genotypes at eight and 20 weeks old.

The sire lines tended to be heavier than the dam lines, except for the A2 genotype. Males were also significantly heavier than females. These results are consistent with previous findings in that dam lines that are selected for egg production show lower live weight as a correlated response and selection for growth traits in sire lines results in increased live weight (Berri et al., 2001; Schmidt et al., 2009; Olutunmogun et al., 2018; Schmidt et al., 2006). The males were heavier than female at all ages. This is consistent with the observation that in chickens males are generally larger than females (e.g. Schmidt et al., 2009). However, the differences could be attributed to the reduced amount of feed provided to the females. 
The primary feathers of genotypes that carry the early feathering gene $(B 1, B 2, A 2)$ were longer than the late-feathering $(A 1, A 3)$ genotypes until the birds were six weeks old, which aligned with previous work (Lou, 1994). Sire lines also had longer primary feathers than the dam lines. The similarity in length of the primary feathers at later ages was consistent with Lou (1994), Moreira et al. (2006) and Bang et al. (2018). The longer primary feathers observed in the sire lines might be because of selection for the growth traits. Previous studies observed longer primary feathers in higher weight genotypes compared with lower weight genotypes (Yang, 1998). The longer primary feathers in females compared with males in one- and twoweek-old chicks were similar to McDougald and Keshavarz (1984), who observed this sexual dimorphism through 24 days old. In the present study, male chicks subsequently had longer primaries than females at 6 , 8 and 20 weeks old. In contrast, Nahashon et al. (2004) observed no significant differences in feather cover between males and females at four and eight weeks old. The lack of a significant difference between the sexes at 12 weeks might be because of moulting, which usually occurs around that age and because male birds moult before females. It had been shown that better feathering at three months old was closely related to higher body growth in the males (Martin, 1929).

The present findings are consistent with the general trend in chickens that indicates under-wing body temperatures increase until the fourth week and then decrease as of the sixth week (Cangar et al., 2008; Moghbeli et al., 2018). This is consistent with the notion that the increasing quality and numbers of feathers on various parts of the body act as insulation and thereby decrease the surface temperature (Richards, 1971). At 4 and 12 weeks, the under-wing temperatures of the B1, B2 and A2 genotypes was higher compared with the A1 and A3 genotypes at one and two weeks old, which is consistent with Dunnington \& Siegel (1985). These differences might be attributable to genetic structures, physiological changes such as moulting (Lourens \& Kuijpers, 2002) and larger muscle mass in sire lines. The lack of significant differences among genotypes at 6,8 , and 20 weeks old is possibly because of the increased rate of feather growth in late feathering birds between five and six weeks old (Özkan et al., 2002). At two weeks old, males had significantly higher under-wing temperatures than females, which might have resulted from the earlier growth rate in males and sexual dimorphism at that age (Leeson \& Walsh, 2004).

Internal body temperature, similar to under-wing temperature, was higher at week 1 in the early feathering genotypes compared with those that feathered later (A1, A3). Similar findings were observed by other researchers (Katanbaf et al., 1989). Therefore, the early feathering birds had better insulation against heat loss during the first weeks of life (O'Sullivan et al., 1991). The later feathering chicks were heavier than the early feathering ones from hatch to 21 days old, which might contribute to their higher internal temperature. At 12 weeks old, rectal temperature was higher in the sire lines than in the dam lines, and also slightly higher in males than females. This may be because of a higher metabolic rate in the males and the sire lines (Piestun et al., 2008). Similar to the present results, Deeb \& Cahaner (1999) reported the absence of a genotype and sex interaction that affected body temperature.

Although there were a few significant correlations, no clear relationship was observed between age and body temperature. Cooper and Washburn (1998) likewise indicated that feather cover was not correlated with body temperature at any age, irrespective of ambient temperature. However, Cahaner et al. (1993) reported that at high ambient temperature, feather coverage was associated positively with body temperature.

There was a positive relationship between live weight and length of the primary feather in A2, B1, and B2 genotypes at six weeks. This correlation might be because of the higher live weight and length of primary feathers recorded in sire lines and in the A2 genotype at that age. Edriss (1988) reported that the length of the tail feather had a positive genetic correlation with the bodyweight of 0.605 in late feathering genotypes.

Pearson's correlation between under-wing and rectal temperature was positive and significant $(P<0.001)$ at all ages, except at hatching. Giloh et al. (2012) made a similar observation of the correlation between cloacal temperature with facial surface temperature in broiler chickens. Because no correlation was observed between rectal and under-wing temperatures at hatch, this may be attributed to the temperature and humidity for hatching chicks, which could affect the under-wing temperatures.

\section{Conclusion}

The length of primary feathers did not appear to correlate with live weight and body temperature. Further studies are needed to determine the effect of the feathering rate on body temperature and live weight by exposing the birds to different ambient temperatures.

\section{Acknowledgements}

The study was supported by Ondokuz Mayis University Project Office (Project number: PYO.ZRT.1901.18.014). 
MS and MN were in charge of conception and design of study. MN and KE participated in the acquisition of data. MN drafted and wrote the manuscript. Critical reviews/revisions and interpreting of data were made by KE and MS. All authors have read and approved the finalized manuscript.

\section{Conflict of Interest Declaration}

We certify no conflict of interest exists regarding the material in this manuscript.

\section{References}

Arrazola, A., Widowski, T., Guerin, M., Kiarie, E. \& Torrey, S., 2020. The effect of alternative feeding strategies on the feeding motivation of broiler breeder pullets. Anim. 1-9. DOI: 10.1017/S1751731120000993

Bang, M.H., Cho, E.J., Cho, C.Y. \& Sohn, S.H., 2018. Study on the characteristics of feather developing pattern and morphology in early- and late-feathering Korean native chickens. Korean. J. Poult. Sci. 45, 155-165. https://doi.org/10.5536/KJPS.2018.45.3.155

Berri, C., Wacrenier, N., Millet, N. \& Le Bihan-Duval, E., 2001. Effect of selection for improved body composition on muscle and meat characteristics of broilers from experimental and commercial lines. Poult. Sci. 80, 833-838. DOI: $10.1093 / \mathrm{ps} / 80.7 .833$

Cahaner, A., Deeb, N. \& Gutman, M., 1993. Effect of plumage reducing naked neck gene on the performance of fastgrowing broilers at normal and high ambient temperatures. Poult. Sci. 72, 767-775.

Cangar, Ö., Aerts, J.M., Buyse, J. \& Berckmans, D., 2008. Quantification of the spatial distribution of surface temperatures of broilers. Poult. Sci. 87, 2493-2499. https://doi.org/10.3382/ps.2007-00326

Chen, X. Y., Wei, P. P., Xu, S. Y., Geng, Z. Y. \& Jiang, R.S., 2013. Rectal temperature as an indicator for heat tolerance in chickens. Anim. Sci. J. 84, 737-9. DOI: 10.1111/asj.12064

Cooper, M.A. \& Washburn, K.W., 1998. The relationships of body temperature to weight gain, feed consumption, and feed utilization in broilers under heat stress. Poult. Sci. 77, 237-242. https://doi.org/10.1093/ps/77.2.237

Darrow, M.I. \& Warren, D.C., 1944. The influence of age on expression of genes controlling rate of chick feathering. Poult. Sci. 23, 199-212.

Deeb, N. \& Cahaner, A., 1999. The effects of naked neck genotypes, ambient temperature, and feeding status and their interactions on body temperature and performance of broilers. Poult. Sci. 78, 1341-1346. https://doi.org/10.1093/ps/78.10.1341

Derks, M.F.L., Herrero-Medrano, J.M., Crooijmans, R., Vereijken, A., Long, J.A., Megens, H.J. \& Groenen M., 2018. Early and late feathering in turkey and chicken: Same gene but different mutations. Genet. Sel. Evol. 50, 7. https://doi.org/10.1186/s12711-018-0380-3

Dunnington, E.A. \& Siegel, P.B., 1985. Long-term selection for 8-week body weight in chickens - Direct and correlated responses. Theor. Appl. Genet. 71, 305-313. https://doi.org/10.1007/BF00252072.

Edriss, M.A., Smith, W.K., Dun, P., 1988. Divergent selection for feather growth in broiler chickens. Proceedings 18th World Poult. Cong., Japan. Pp. 561-56. https://naldc.nal.usda.gov/catalog/CAT10414984

Fotsa, J.C., Merat, P. \& Bordas, A., 2001. Effect of the slow (K) or rapid $\left(\mathrm{k}^{+}\right)$feathering gene on body and feather growth and fatness according to ambient temperature in a Leghorn x brown egg type cross. Genet. Sel. Evol. 33, 659670. https://doi.org/10.1051/gse:2001135

Giloh, M. Shinder, D Yahav, S., 2012. Skin surface temperature of broiler chickens is correlated to body core temperature and is indicative of their thermoregulatory status. Poult. Sci. 91, 175-188

Godfrey, G.F. \& Farnsworth, G.M.J., 1952. Relation of the sex-linked rapid feathering gene to chick growth and mortality. Poult. Sci. 31, 65-68.

Hays, F.A., 1951. Rate of chick feathering and growing chick weight in Rhode Island Reds. Poult. Sci. 30, 866-869. https://doi.org/10.3382/ps.0300866

Hays, F.A., 1952. Sex dimorphism in tail length of chicks at ten days of age. Poult. Sci. 31, 1093. https://doi.org/10.3382/ps.0311093

Katanbaf, M.N., Dunnington, E.A. \& Siegel, P.B., 1989. Restricted feeding in early and late-feathering chickens 2. Reproductive responses. Poult. Sci. 68, 352-358. DOI: 10.3382/ps.0680352

Khosravinia, H., 2009. Effect of the slow $(\mathrm{K})$ or rapid $\left(\mathrm{k}^{+}\right)$feathering gene on carcass-related traits of broiler chickens selected for breast and thighs weight. Rus. J. Genet. 45, 98-104. https://doi.org/10.1134/S1022795409010141

Leeson, S. \& Walsh, T., 2004. Feathering in commercial poultry. II: Factors influencing feather growth and feather loss. World's Poult. Sci. 60, 52-63.

Lou, M., 1994. Genetic evaluation of the effects of divergent feathering selection and major feathering genes on growth performances and carcass traits in broiler chickens. PhD thesis, University of Glasgow.

Lourens, A. \& Kuijpers, M., 2002. Control temperature of young chicks to reduce mortality. World Poult. 18, 24-26.

Mahmoud, B.Y., Abdel Hafez, A.S., Emam, A.M., Abdelmoniem, A.M. \& El Safty, S.A., 2018. Feathering rate impact on growth and slaughter traits of Japanese quail. J. Agric. Sci. 156, $942-948$. https://doi.org/10.1017/S0021859618001089

Martın, J.H., 1929. Rate of feather growth in Barred Plymouth Rock chicks. Poult. Sci. 8, $167-183$. https://doi.org/10.3382/ps.0080167

McDougald, L.R. \& Keshavarz, K., 1984. The effect of polyether ionophore anticoccidial drugs on feather growth in genetically slow-feathering broilers. Poult. Sci. 63, 1322-1326. DOI: 10.3382/ps.0631322 
Moghbeli, D.M., Barazandeh, A., Sattaei, M.M., Esmaeilipour,O. \& Badakhshan, Y., 2018. Evaluation of body surface temperature in broiler chickens during the rearing period based on age, air temperature and feather condition. Iranian. J. Anim. Sci. 8, 499-504.

Moreira, J., Mendes, A.A., Garcia, R.G., Garcia, E.A., Roça, R.O., Nääs, I.A., Dalanezi, J.A. \& Pelícia, K., 2006. Evaluation of strain, dietary energy level and stocking density on broiler feathering. Rev. Bras. Ciênc. Avi. 8,1522. http://dx.doi.org/10.1590/S1516-635X2006000100002

Nahashon, S.N., Bartlett, J. \& Smith, E.J., 2004. Effect of the late-feathering or early feathering genotypes on performance and carcass traits of broiler chickens. Livest. Prod. Sci. 91, 83-94. https://doi.org/10.1016/j.livprodsci.2004.06.010

Nickel, R., Schummer, A. \& Selferle, E., 1992. Lehrbuch der Anatomie der Haustiere. Anatomie der Vögel. 2nd ed. Vol. 5. Parey, Berlin.

Olutunmogun, A.K., Umar, A.U., Adejoh-Ubani, E.O., Nwagu, B.I., Adeyinka, I.A. \& Muhammad, S.M., 2018. Effect of egg size and lines on hatching performance of chicks from broiler breeders under selection. J. Anim. Prod. 45, 1825

O'Sullivan, N.P., Dunnington, E.A. \& Siegel, P.B., 1991. Growth and carcass characteristics of early and late-feathering broilers reared under different feeding regimens. Poult. Sci. 70, 1323-1332. https://doi.org/10.3382/ps.0701323

Ozkan, H., Brandolini, A., Schafer-Pregl, R. \& Salamini, F., 2002. AFLP analysis of a collection of tetraploid wheats indicates the origin of emmer and hard wheat domestication in southeast Turkey. Mol. Biol. Evol. 19, 1797-1801. https://doi.org/10.1093/oxfordjournals.molbev.a004002

Piestun, Y., Shinder, D., Ruzal, M., Halevy, O. \& Yahav, S., 2008. The effect of thermal manipulations during the development of the thyroid and adrenal axes on in-hatch and post-hatch thermoregulation: J. Therm. Biol. 7, 413418. https://doi.org/10.1016/j.jtherbio.2008.06.007

Richards, S.A., 1971. The significance of changes in the temperature of the skin and body core of the chicken in regulation of heat loss. J. Physiol. 216, 1-10. DOI: 10.1113/jphysiol.1971.sp009505

Sarica, M., Caglak, S., Oguzhan, E., Ozkan, I., Kilic, F., Tok, S., 2016. Türkiye Etlik Piliç Ebeveynleri Islah Projesi. Ulusal Kümes Hayvanları Kongresi. pp: 29-40.

Schmidt, C.J., Persia, M.E., Feierstein, E., Kingham, B. \& Saylor, W.W., 2009. Comparison of a modern broiler line and a heritage line unselected since the 1950s. Poult. Sci. 88, 2610-2619. DOI: 10.3382/ps.2009-00055

Schmidt, G.S., Figueiredo, E.A.P. \& Ledur, M.C., 2006. Genetic gain for body weight, feed conversion and carcass traits in selected broiler strains. Rev. Bras. Ciênc. Avi. 8, 29-32. https://doi.org/10.1590/S1516-635X2006000100004

Serebrovsky, A.S., 1922. Crossing over involving three sex-linked genes in chickens. Americ Nat. 56, 571-572. https://doi.org/10.1086/279898

Sharifi, R.A., 2004. Reproduktives Adaptationsvermögen von Broiler-Muttertieren bei hohen Umwelttemperaturen unter Nutzung spezieller Majorgene. Dr. rer. Agr thesis, Univ. Berlin. Cuvillier Verlag. Göttingen.

Warren, D.C.,1925. Inheritance of rate of feathering in poultry. J. Hered. 16,13-18. https://doi.org/10.1093/oxfordjournals.jhered.a102502

Xie, M., Liu, L., Jinfang, X., Tang, W., Wu, Y., Huang, L., Chen, W., Kang, Z., Chu, Y. \& Ji Hua, Y., 2013. Studies on breeding of rapidly feathering pure line and slowly feathering pure line of Anyi tile-like gray chicken and its autosexing technology: Acta. Agri. J. 25, 84-88. https://www.semanticscholar.org/paper/Studies-on-breeding-ofrapidly-feathering-pure-line-MingGui-Lin-xiu/624b210b5cb42fd2f79cc528e287671c30a201bf

Yalcin, S., Settar, P., Ozkan, S. \& Cahaner, A., 1997. Comparative evaluation of three commercial broiler stocks in hot versus temperate climates. Poult. Sci. 76, 921-929. https://doi.org/10.1093/ps/76.7.921

Yang, A., 1998. Bilateral asymmetry in chickens of different genetic backgrounds. PhD thesis, Virginia Polytechnic Institute and State University, Blacksburg. 